\title{
Carbon stock in the development of different designs of biodiverse agroforestry systems
}

\author{
Cinira de A. F. Fernandes ${ }^{1}$, Sylvana N. Matsumoto ${ }^{2} \&$ Volney S. Fernandes ${ }^{3}$ \\ ${ }^{1}$ Universidade Estadual do Sudoeste da Bahia/Instituto Federal de Educação, Ciência e Tecnologia Baiano/Campus Uruçuca. Uruçuca, BA. E-mail: cinira. \\ farias@urucuca.ifbaiano.edu.br (Corresponding author) - ORCID: 0000-0002-9281-8293 \\ ${ }^{2}$ Universidade Estadual do Sudoeste da Bahia. Vitória da Conquista, BA. E-mail: snaomi@uesb.edu.br - ORCID: 0000-0002-7182-6745 \\ ${ }^{3}$ FLORAR Sustentabilidade. Ilhéus, BA. E-mail: volneyfernandes@gmail.com - ORCID: 0000-0002-7403-732X
}

\section{Key words:}

agroforestry

Theobroma cacao

Hevea brasiliensis

biodiverse system

\begin{abstract}
A B S T R A C T
The objective of this study was to estimate the carbon stock in the different designs of biodiverse agroforestry systems (AFSs) in the region of the Environmental Protection Area (EPA) of Pratigi, Bahia, Brazil. Phytosociology aspects related to the potentiality of carbon stock of 10 farms were evaluated using plots of $10 \times 50 \mathrm{~m}$ allocated in each AFS, inventorying 928 individuals of 17 families and 37 species, established in 2013. The biomass above and below the soil of the arboreal individuals were estimated by indirect method, using specific allometric equations for each species or group of species, with diameter above $1 \mathrm{~cm}$. Carbon stock (CS) was estimated from the biomass. Cacao (Theobroma cacao) and rubber tree (Hevea brasiliensis) were the dominant species in all of the designs, which also contained fruit trees, and native and exotic shade trees. There was variation of the estimate of carbon stock (8.01-1.42 $\mathrm{Mg} \mathrm{ha}^{-1}$ ) between the types of AFSs. The designs with a larger relative density of fruit and shade trees led to larger carbon storage, influenced by the wealth and diversity of species in the initial phase of establishment of biodiverse AFSs.
\end{abstract}

\section{Palavras-chave:} agrofloresta Theobroma cacao Hevea brasiliensis sistema biodiverso

\section{Estoque de carbono no desenvolvimento de diferentes desenhos de sistemas agroflorestais biodiversos}

\section{R E S U M O}

Objetivou-se, neste estudo, estimar o estoque de carbono nos diferentes desenhos de sistemas agroflorestais (SAFs) biodiversos na região da Área de Proteção Ambiental (APA) do Pratigi, Bahia. Foram avaliados aspectos da fitossociologia relacionados a potencialidade de estoque de carbono de 10 propriedades, utilizando parcelas de $10 \times 50 \mathrm{~m}$ alocadas em cada um dos SAFs, sendo inventariados 928 indivíduos de 17 famílias e 37 espécies, implantados em 2013. A biomassa acima e abaixo do solo, dos indivíduos arbóreos foi estimada pelo método indireto, utilizando equações alométricas específicas para cada espécie ou grupo de espécies, com diâmetro acima de $1 \mathrm{~cm}$. Estimou-se a partir da biomassa o estoque de carbono (EC). $\mathrm{O}$ cacau (Theobroma cacao) e a seringueira (Hevea brasiliensis) foram as espécies dominantes em todos os desenhos, sendo constituídos também por frutíferas, árvores de sombra nativas e exóticas. Houve variação da estimativa de estoque de carbono (8,01-1,42 $\left.\mathrm{Mg} \mathrm{ha}^{-1}\right)$ dentre os tipos de SAFs. Os desenhos com uma maior densidade relativa de frutíferas e árvores de sombra proporcionaram um maior armazenamento de carbono, influenciados pela riqueza e diversidade de espécies na fase inicial de implantação de SAFs biodiversos. 


\section{INTRODUCTION}

Changes in climate regimes affect food security and food production, with direct and indirect effects on agricultural activity, and agroforestry systems are recognized as an alternative to mitigate such impacts (Kirsch \& Schneider, 2016). The possibility of food cultivation in agroforestry refers to several types of environmental services, with great current relevance to those related to carbon sequestration and fixation, aligning the needs of adaptation and mitigation of climate change (Somarriba et al., 2013).

The management of agroforestry systems has high potential for carbon sequestration due to multi-layered architecture, with shrub and tree species that occupy different niches in vertical and horizontal directions (Canuto et al., 2014). However, there is a variation in the amount of carbon stock, related to the design and tree species that make up the system (Brianezi et al., 2013).

In spite of the verification of the real socio-economic and environmental benefits resulting from the adoption of biodiverse AFSs by farmers, the knowledge base on this subject in the region of the Environmental Protection Area (EPA) of Pratigi needs to consolidate this form of cultivation. The conservation value of AFSs can be influenced by the intensification of management practices, such as species design and selection, and agroecological management (Armengot et al., 2016).

From the composition and density of the species, an AFS design can be established with a balance between environmental conditions favorable to cacao yield and maintenance of environmental services (Deheuvels et al., 2014).

In this context, this study was conducted with the purpose of establishing the relationship between the species in different designs of biodiverse AFSs and carbon stock, in their initial phase of development.

\section{Material AND Methods}

The study was carried out in a microregion in the environmental protection area of Pratigi (EPAof Pratigi, $39^{\circ}$ $07^{\prime} \mathrm{W}, 39^{\circ} 13^{\prime} \mathrm{W}$ and $13^{\circ} 30^{\prime} \mathrm{S}, 13^{\circ} 52^{\prime} \mathrm{S}$ ), inserted in the ombrophilous forest (perennial-rainforest) biome called Mata Atlântica (Atlantic forest), municipalities of Piraí do Norte and Ibirapitanga, Bahia, Brazil (Figure 1).

This region is characterized by considerable rainfall, with vegetation in areas of primary and secondary forests. The predominant climate in the region is Tropical rainforest (Af) and Tropical monsoon (Am), according to the classification of Köppen. The precipitation is higher than $60 \mathrm{~mm}$ for the driest month and the total annual mean is above $1600 \mathrm{~mm}$, with mean temperature of $24^{\circ} \mathrm{C}$ and relative air humidity around 80\% (CRA, 2000). Soil classification indicates a predominance of abrupt (or not) yellowish Argisol, sandy/clayey texture, undulating or strongly undulating phase + Haplic Cambisol Typical $\mathrm{Tb}$, clayey medium texture, strong undulating relief phase, both Moderate Dystrophic A (CRA, 2000).

The plots were established in ten small farms of family farmers, where each one has one hectare of biodiverse AFS,

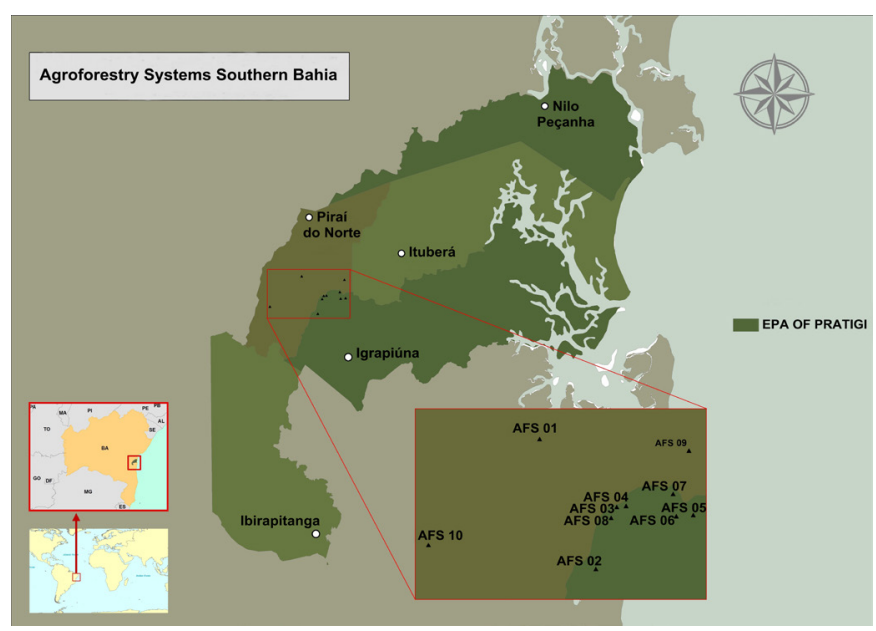

Figure 1. Location of the environmental protection area of Pratigi, Bahia, Brazil

aged four years, established in an abandoned pasture area, with the purpose of recovering unproductive areas, and the designs of these systems were defined in a participatory manner between Technical Assistance and Rural Extension professionals and farmers. Therefore, 10 rectangular plots of $10 \times 50 \mathrm{~m}\left(500 \mathrm{~m}^{2}\right)$ were leased, one in each farm.

AFS designs were characterized by dominant species (cacao and rubber trees) and groups of arboreal species according to their function in the system. The functions were differentiated in species of commercial use (fruit trees), characterized by the commercialization of the fruits, and native and exotic species (shade trees). All trees present in the plot were identified by popular names, with the help of farmers. These data were used to determine the absolute density, relative density of cacao trees, rubber trees, shade trees, wealth, ShannonWeaver diversity index $\left(\mathrm{H}^{\prime}\right)$. This index expresses wealth and uniformity and in its calculation considers as equal rare and abundant species, and generally this index is usually between 1.5 and 3.5 (Magurran, 1989).

The evaluation of the amount of biomass was carried out using the indirect method. In this method, biomass can be inferred through plot-level measurement of structural variables, using allometric equations specific to each species or group of species, considering the local situation (climate, ecosystem, and species) from measurements of diameter and height of the trees (Table 1) (Pearson et al., 2005).

For native trees and rubber trees, individuals with diameter equal to or greater than $1.27 \mathrm{~cm}$, measured with bark, at a height of $1.3 \mathrm{~m}$ (DBH, diameter at breast height) were used. For cacao and fruit trees the diameter determination was performed at $30 \mathrm{~cm}$ from the soil, maintaining the bark, in individuals with diameter equal to or greater than $1 \mathrm{~cm}$. For palm trees occurring in clumps, such as açaí and cacao, each stipe represented an individual (Pearson et al., 2005).

After determination of the biomass above the soil, the biomass under the soil was calculated, through the root-shoot ratio. For this, the above-ground biomass was multiplied by the factor 0.22 according to the Protocol of measurement and estimation of biomass and forest carbon of EMBRAPA (Higa et al., 2014) based on studies conducted by Mokany et al. (2006). 
Table 1. Allometric equations used to estimate the total aerial biomass of the tree components of different species in the studied models

\begin{tabular}{|c|c|c|c|}
\hline $\begin{array}{l}\text { Species or group } \\
\text { of species }\end{array}$ & Equation & $\begin{array}{c}\text { Interval } \\
\text { of DBH (cm) }\end{array}$ & Author (s) \\
\hline Native species & $Y=21.297-6.953 * \mathrm{DBH}+0.74 *\left(\mathrm{DBH}^{2}\right)$ & $>4$ & Tiepolo et al. (2002) \\
\hline Native species & $\mathrm{Y}=-2.292+0.369 *(\mathrm{DBH})+0.087{ }^{*} \mathrm{H}$ & $1.27-4$ & Saldarriaga et al. (1988) \\
\hline Cacao & $Y=10^{(-1.625+2.63 * \operatorname{LGG}(D 30))}$ & $1.3-26.8$ & Andrade et al. (2008) \\
\hline Palm trees & $Y=\exp (-6.3789+0.877 \ln (1 /(\mathrm{DBH}) 2)+2.151 \ln (\mathrm{H}))$ & & Saldarriaga et al. (1988) \\
\hline Fruit trees & $Y=10^{(-1.11+2.64 * \operatorname{LOG}(\mathrm{D30}))}$ & $1.9-46.5$ & Andrade et al. (2008) \\
\hline Peach palm & $Y=0.97+0.07 * B A-0.949 \times 10^{-3} * B A^{2}+0.65 \times 10^{-5} * B A^{3}$ & $2-12$ & Schroth et al. (2002) \\
\hline Shade Rubber trees & $Y=\exp (-0.834+2.223(\log 10 \mathrm{D} 30))$ & Up to 44 & Segura et al. (2006) \\
\hline
\end{tabular}

$\mathrm{Y}$ - Dry biomass above ground $(\mathrm{kg})$; DBH - Diameter at breast height $(1.3 \mathrm{~m})$ in $\mathrm{cm} ; \mathrm{H}$ - Height; D30 - Diameter at 30 from soil surface; BA - Basal area; BA - $\pi \times(\mathrm{DBH} / 2)^{2}$

For the calculation of the total dry biomass (DB) of the plot, the sum of the biomass above and below the soil was used. After determination of the DB of each individual, the biomass per plot was calculated, the result being expressed in $\mathrm{Mg} \mathrm{ha}^{-1}$. Carbon stock (CS) estimation was performed by multiplying by the DB factor of 0.485 , because DB contains approximately $48.5 \%$ of carbon (Montagnini \& Nair, 2004).

Data were tabulated and analyzed using ASSISTAT software, version 7.7, SAEG, version 9.1 and Microsoft Excel 2010. To verify the association between the variables, the Pearson linear correlation analysis was carried out. The methodology of dissimilarity grouping, Tocher's method, presented in Cruz \& Carneiro (2006) was used. For this grouping, the carbon stock and the diversity index of Shannon-Weaver were considered, since they were the most important characteristics for this study.

\section{Results AND Discussion}

In the 10 AFSs, 928 arboreal individuals belonging to 17 families and 37 species were analyzed (Table 2). The floristic classification indicates that the five most representative families were: Fabaceae (eight species), Anacardiaceae (four species),

Table 2. Tree composition of the ten plots of the biodiverse AFSs in Pratigi EPA, Bahia, Brazil

\begin{tabular}{|c|c|c|c|c|c|}
\hline Family & Scientific name & Popular name & Total & Plot (AFS) & Species group \\
\hline Anacardiaceae & Schinus terebinthifolius & Aroeira & 4 & $8-9$ & NST \\
\hline Anacardiaceae & Mangifera indica & Manga & 2 & $2-3$ & $\mathrm{~F}$ \\
\hline Anacardiaceae & Tapiriramar chandii & Pau Pombo & 1 & 9 & NST \\
\hline Annonaceae & Rollinia deliciosa & Biriba & 1 & 5 & NST \\
\hline Annonaceae & Annona muricata & Graviola & 4 & $1-2$ & $\mathrm{~F}$ \\
\hline Bignoniaceae & Tabebuia ochracea & Ipê & 2 & 8 & NST \\
\hline Caricaceae & Carica papaya & Mamão & 19 & $5-6-7-8$ & $\mathrm{~F}$ \\
\hline Euphorbiaceae & Hevea brasiliensis & Seringueira & 96 & All & D \\
\hline Fabaceae & Anadenanthera colubrina & Angico & 1 & 2 & NST \\
\hline Fabaceae & Gliricidia sepium & Gliricídia & 42 & $2-3-4-5-6-7-8-10$ & EST \\
\hline Fabaceae & Inga edulis & Ingá & 14 & 6-7-8 & NST \\
\hline Fabaceae & Inga marginata & Ingá Periquito & 7 & $6-10$ & NST \\
\hline Fabaceae & Albizzia angolensis & Muanza & 6 & 8 & NST \\
\hline Fabaceae & Caesalpinia pluviosa & Sibipiruna & 1 & 10 & NST \\
\hline Lamiaceae & Aegiphila sellowiana & Fidalgo & 1 & 8 & NST \\
\hline Lauraceae & Persea americana & Abacate & 3 & $5-6$ & $\mathrm{~F}$ \\
\hline Lauraceae & Laurus nobilis & Louro & 2 & 8 & NST \\
\hline Lecythidaceae & Cariniana legalis & Jequitibá & 7 & $6-7-10$ & NST \\
\hline Malvaceae & Theobroma cacao & Cacau & 581 & All & D \\
\hline Malvaceae & Spondias mombin & Cajá & 4 & $4-5-10$ & $\mathrm{~F}$ \\
\hline Malvaceae & Theobroma grandiflorum & Cupuaçu & 50 & $2-3-4-5-6-7-8-9$ & $\mathrm{~F}$ \\
\hline Malvaceae & Heliocarpus popayanensis & Pau jangada & 1 & 6 & NST \\
\hline Meliaceae & Swietenia macrophylla & Mogno & 3 & 8 & EST \\
\hline Myrtaceae & Psidium guineense & Araçá & 1 & 8 & NST \\
\hline Myrtaceae & Syzygium aromaticum & Cravo & 1 & 2 & $\mathrm{~F}$ \\
\hline Myrtaceae & Psidium guajava & Goiaba & 3 & $1-7$ & $\mathrm{~F}$ \\
\hline Myrtaceae & Syzygiumaqueum & Jambo Branco & 1 & 2 & NST \\
\hline Palm trees & Euterpe oleracea & Açaí & 12 & $7-8-9$ & $\mathrm{~F}$ \\
\hline Rubiaceae & Genipa americana & Jenipapo & 3 & $2-10$ & $\mathrm{~F}$ \\
\hline Rutaceae & Citrus limon & Limão & 1 & 10 & $\mathrm{~F}$ \\
\hline Sapotaceae & Manilkara huberi & Maçaranduba & 7 & $7-9-10$ & NST \\
\hline Verbenaceae & Cytharexylum myrianthum & Pau viola & 2 & $2-5$ & NST \\
\hline 17 Families & 37 Species & \multicolumn{4}{|c|}{928 Individuals } \\
\hline
\end{tabular}

NST - Native Shade Trees; EST - Exotic Shade Trees; F - Fruit Trees; D - Dominant 
Malvaceae (four species) and Myrtaceae (four species), constituting $40.12 \%$ of the total species listed.

For the designs of AFSs regarding their tree composition when related to the profile of the farmer (Table 2), it was observed that their design is linked to yield. Farmers who have retirement or other incomes outside the AFS make an option for lower concentration of cacao and larger concentration of native species, in contrast to those who have AFS as one of the main incomes.

In the Soubre region, located in the Republic of Côte d'Ivore, it was verified the preference of small farmers less financially benefited and those isolated from the larger centers for the introduction of tree species whose products had high demand in the local community (Gyau et al., 2015). The possibility of producing crops with high value in large markets was not an important factor in the choice of species composition of AFSs by these farmers.

This result was reported by other authors such as Tsuchiya \& Hiraoka (1999) for whom the farmer's profile defined the dominant crop and the number of shade species as a function of common agricultural practices in the region. For Donato \& Lima (2014) the designs were influenced by economic characteristics, popular knowledge, ecological knowledge about the species and regional climatic conditions of the Ribeira Valley, in the state of São Paulo.

In the AFSs of this study, the designs led to differences in the carbon stock, varying from 1.42 to $8.01 \mathrm{t} \mathrm{ha}^{-1}$ (Figure 2A), reflex of the different densities and species diversity that compose them. Similar data were found by Torres et al. (2014) in which the different designs studied in biodiverse AFSs varied the carbon content according to the established arrangement and the age of the system.

In all ten plots of AFSs, land use patterns were identified with individuals at different stages of vegetative development, however, there was difference between structural and floristic information, and carbon content estimates. The designs were classified by dissimilarity into three groups, from the potential of the quantified carbon stock and Shannon-Weaver diversity index (Table 3, Figure 2A). CS conditioned the largest contribution to the proposed grouping in relation to the Shannon-Weaver diversity index.

When the relative density of the main components of the AFSs is observed, it is verified that the increase of the relative density of shade trees and fruit trees and the reduction of the relative density of cacao trees are associated with the greater capacity of carbon stock (Figure 2B). The wealth and diversity of species evaluated from the Shannon-Weaver diversity index $\left(\mathrm{H}^{\prime}\right)$ also have a great relation with the carbon stock potential of the AFSs under study (Figures 2C and D). This fact was previously corroborated by Noiha et al. (2015).

Table 3. Grouping based on measures of similarity between attributes, according to their characteristics (variables), relating the items in groups, from the Tocher's method, considering the Euclidean distances

\begin{tabular}{ccc}
\hline Group & Number & Belonging individuals \\
1 & 4 & $2,5,4,10,7$ \\
2 & 3 & $1,9,3$ \\
3 & 2 & 2,9 \\
\hline
\end{tabular}
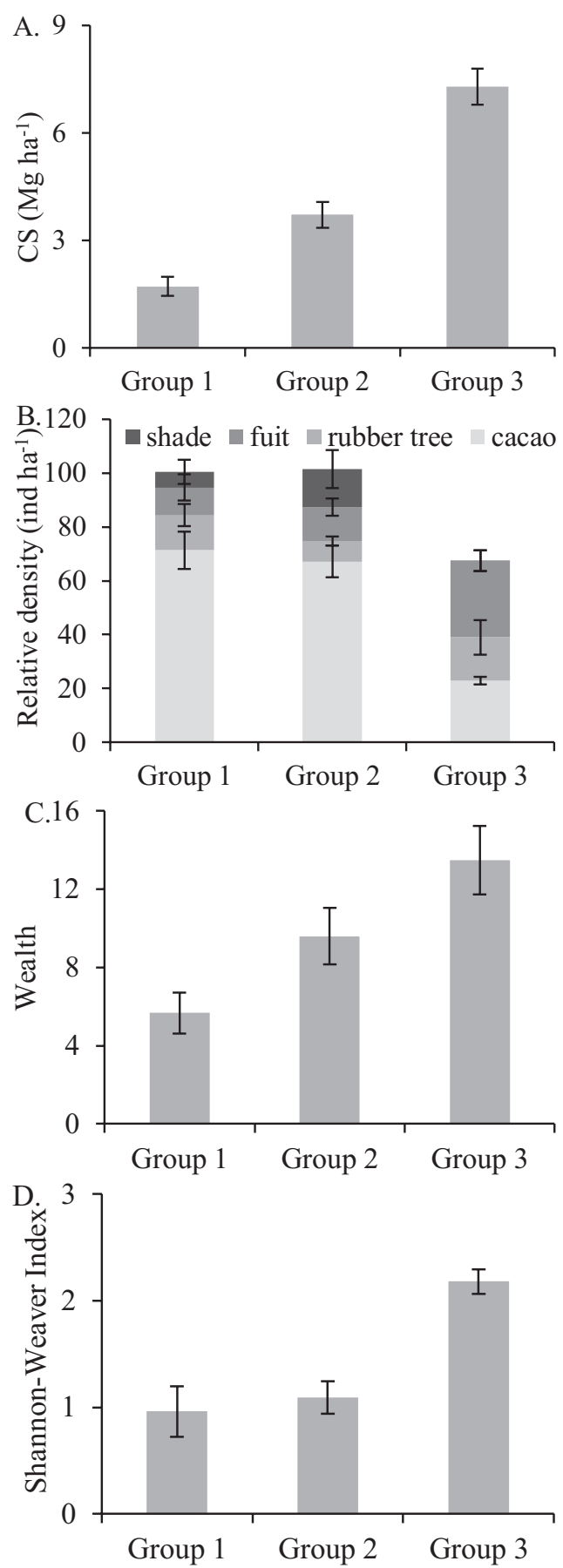

Figure 2. (A) Carbon stock - CS (Mg ha-1); (B) relative density of cacao trees, rubber trees, shade trees, and fruit trees; (C) wealth; (D) Shannon-Weaver diversity index (H') (D) evaluated in agroforestry systems located in Pratigi EPA, Bahia, Brazil

The AFSs of Group 3 had higher estimates of carbon stock, in relation to the other groups (Figure 2A). This result was attributed to its composition, prioritizing the native tree component (Figure 2C). In a study conducted by Kurzatkowskiet al. (2007), similar results were obtained, in which the design of arboreal composition with the occurrence of large trees planted in suitable spacing for each species allows the rapid growth, reflecting the total biomass and carbon stock.

Wealth, diversity $\left(\mathrm{H}^{\prime}\right)$, and relative density of fruit trees maintained positive correlation with the carbon stock potential of the systems (Table 4). Because these were AFSs 
Table 4. Pearson's linear correlation matrix between the variables used in the quantification of AFS carbon in Pratigi EPA, Bahia Brazil

\begin{tabular}{|c|c|c|c|c|c|c|c|}
\hline & Wealth & H' $^{\prime}$ & AD & FTD & STD & CTD & RTD \\
\hline CS & $0.7836^{* *}$ & $0.7319^{*}$ & 0.2526 & $0.6862^{*}$ & 0.5920 & $-0.7096^{*}$ & 0.0980 \\
\hline Wealth & - & $0.7715^{*}$ & 0.2156 & $0.7290^{*}$ & $0.6877^{*}$ & $-0.7046^{*}$ & -0.2641 \\
\hline $\mathrm{H}^{\prime}$ & - & - & -0.2784 & $0.8324^{* *}$ & $0.8920^{\star *}$ & $-0.9748^{\star *}$ & 0.0151 \\
\hline$A D$ & - & - & - & 0.0497 & -0.4429 & 0.3607 & -0.1452 \\
\hline FTD & - & - & - & - & -0.2348 & $-0.8383^{\star *}$ & -0.0395 \\
\hline STD & - & - & - & - & - & $-0.8637^{\star *}$ & -0.2348 \\
\hline CTD & - & - & - & - & - & - & -0.1764 \\
\hline
\end{tabular}

CS - Carbon Stock; Wealth - Wealth; H' - Shannon-Weaver index; FTD - Fruit tree relative density, STD - Shade trees relative density, CTD - Cacao trees relative density, RTD - Rubber trees relative density, $A D-$ Absolute density. ** Significant at 0.01 probability level $(p<0.01)$; * Significant at 0.05 probability level $(0.01 \leq p<0.05)$; NS - Not significant $(p \geq 0.05)$; t-test at levels of 0.05 and 0.01

with four years of establishment, the carbon sequestration potential of shade trees had less expression in relation to fruit trees. The initial vigorous growth of fruit trees was a factor associated with this response, similar to that verified by Silatsa et al. (2017).

The relative density of cacao trees maintained negative correlation with the carbon stock, wealth, $\mathrm{H}^{\prime}$, relative density of fruit trees, and shade trees (Table 4). The increase in the relative density of cacao trees, considered as crop intensification, is observed in many areas of AFSs of cacao trees, being a restriction factor for the insertion of shade trees and fruit trees, reducing the carbon content of the system (Magne et al., 2014; Vaast \& Somarriba, 2014).

Decision-making in the establishment of a biodiverse AFS, even taking into account the objectives of each farmer and the local potentialities, tends to form agroecosystems with good multiplicity of use, generating sustainable model of agriculture and at the same time a supplier of environmental services, making these strategic systems to mitigate greenhouse gas (GHG) emissions.

\section{Conclusions}

1. The intensification of cacao plantations results in restriction of carbon stock capacity in the initial phase of establishment of biodiverse AFSs.

2. The designs with higher relative density of fruit trees and shade trees led to greater carbon storage in the initial phase of establishment of biodiverse AFSs.

3. The wealth, diversity of species, are directly related to the greater carbon sequestration potential of cocoa AFSs.

\section{Acknowledgments}

The research was supported by $\mathrm{CNPq}$, the Earth Conservation Organization (OCT), State University of Southwestern Bahia (UESB) and Federal Institute of Bahia (IF Baiano). We appreciate the collaboration of the owners of the areas where this study was carried out.

\section{Literature Cited}

Andrade, H. J.; Segura, M.; Somarriba, E.; Villalobos, M. Valoración biofísica y financiera de la fijación de carbono por uso del sueloen fincas cação teras indígenas de Talamanca, Costa Rica. Agroforestería en las Américas, v.46, p.45-50, 2008.
Armengot, L.; Barbieri, P.; Andres, C.; Milz, J.; Schneider, M. Cacao agroforestry systems have higher return on labor compared to full-sun monocultures. Agronomy Sustainable Development, v.1, p.36-70,2016. https://doi.org/10.1007/s13593-016-0406-6

Brianezi, D.; Jacovine, L. A. G.; Soares, C. P. B.; Castro, R. V. O.; Basso, V. M. Allometric equations for estimating carbono furban trees in Viçosa-MG. Revista Árvore, v.37, p.1073-1081, 2013. https:// doi.org/10.1590/S0100-67622013000600009

Canuto, J. C.; Ramos Filho, L. O.; Camargo, R. C. R.; Silva, F. F. da; Junqueira, A. da C.; Silva, J. P. da; Galvão, A. C. Quintais agroflorestais como estratégia de sustentabilidade ecológica e econômica. In: Encontro da Rede de Estudos Rurais, 6, 2014, Campinas, Anais... Rio de Janeiro: Rede de Estudos Rurais, 2014. CD Rom.

CRA - Centro de Recursos Ambientais. Plano de manejo da APA do Pratigi. Salvador, 2000. Available on: <http://www.inema.ba.gov. br/wpcontent/uploads/2011/09/PM _APA_Pratigi_Encarte-I. pdf>. Access on: May 2017.

Cruz, C. D.; Carneiro, P. C. S. Modelos biométricos aplicados ao melhoramento genético. 2.ed. Viçosa: UFV, 2006. 585p.

Deheuvels, O.; Rousseau, G. X.; Quiroga, G. S.; Franco, M. D.; Cerda, R.; Mendoza, S. J. V.; Somarriba, E. Biodiversity is affected by changes in management intensity of cocoa-based agroforests. Agroforestry Systems, v.88, p.1081-1099, 2014. https://doi. org/10.1007/ s10457-014-9710-9.

Donato, L.; Lima, M. das G. de. Distribuição geográfica do sistema agroflorestal na região do Vale do Ribeira. Geografia, v.22, p.47-64, 2014. https://doi.org/10.5433/2447-1747.2013v22n3p47.

Gyau, A.; Smoot, K.; Diby, L.; Kouame, C. Drivers of tree presence and densities: The case of cocoa agroforestry systems in the Soubre region of Republic of Côte d'Ivoire. Agroforestry Systems, v.89, p.149-161, 2015. https://doi.org/10.1007/s10457-014-9750-1

Higa, R. C. V.; Cardoso, D. J.; Andrade, G. C.; Zanatta, J. N.; Brum, B. M.; Pulrolnik, R. K.; Nicodemo, M. F. L.; Garrastazu, M. C.; Vasconcelos, S. S.; Salis, S. M. Protocolo de medição e estimativa de biomassa e carbono florestal. 1.ed. Colombo: Embrapa Florestas, 2014. 81p.

Kirsch, H. M.; Schneider, S. Vulnerabilidade social às mudanças climáticas em contextos rurais. Revista Brasileira de Ciências Sociais, v.31,p.1-15, 2016. https://doi.org/10.17666/319106/2016

Kurzatkowski, D. Potencial do sequestro de carbono nos sistemas agroflorestais: Análise dos quatro sistemas implantados no município de Pium - TO. Revista Carbono Social, v.1, p.75-80, 2007.

Magne, A. N.; Nonga, N. E.; Yemefack, M.; Robiglio, V. Profitability and implications of cocoa intensification on carbon emissions in Southern Cameroun. Agroforestry Systems, v.88, p.1133-1142, 2014. https://doi.org/10.1007/s10457-014-9715-4

Magurran, A. E. Diversidad ecologica y su medición. Barcelona: Ediciones Vedra, 1989. 199p. 
Mokany, K.; Raison, J. R.; Prokushkin, A. S. Critical analysis of root: Shoot ratios in terrestrial biomes. Global Change Biology, v.12, p.84-96, 2006. https://doi.org/10.1111/j.1365-2486.2005.001043.x

Montagnini, F.; Nair, P. K. R. Carbon sequestration: An underexploited environmental benefit of agroforestry systems. Agroforestry Systems, v.61, p.281-295, 2004. https://doi.org/10.1007/978-94017-2424-1_20

Noiha, N. V.; Zapfack, L.; Mbade, L. F. Biodiversity management and plant dynamic in a cocoa agroforest. International Journal of Plant and Soil Science, v.6, p.101-108, 2015. https://doi.org/10.9734/ IJPSS/2015/10347

Pearson, T.; Walker, S.; Brown, S. Sourcebook for land use, land-use change and forestry projects. Available on: <http://documents. worldbank.org/curated/en/2013/01/18009480/sourcebook-landuse-land-use-change-forestry-projects $>$. Access on: Mar. 2017.

Saldarriaga, J. G.; West, D. C.; Tharp, M. L.; Uhl, C. Long term chrono sequence of forest secession in the upper Rio Negro of Colombia and Venezuela. Journal Ecology, v.76, p.938-958, 1988. https:// doi.org/10.2307/2260625

Schroth, G.; D’Angelo, S. A.; Teixeira, W. G.; Haag, D.; Lieberei, R. Conversion of secondary forest into agroforestry and monoculture plantations in Amazonia: Consequences for biomass, litter and soil carbon stocks after seven years. Forest Ecology and Management, v.163, p.131-150, 2002. https://doi.org/10.1016/ S0378-1127(01)00537-0

Segura, M.; Kanninen, M.; Suárez, D. Allometric models for estimating aboveground biomass of shade trees and coffee bushes grown together. Agroforestry Systems, v.68, p.143-150, 2006. https:// doi.org/10.1007/s10457-006-9005-x
Silatsa, F. B. T.; Yemefack, M.; Ewane-Nonga, N.; Kemga, A.; Hanna, R. Modeling carbon stock dynamics under fallow and cocoa agroforest systems in the shifting agricultural landscape of Central Cameroon. Agroforesty Systems, v.1, p.993-1006, 2017. https:// doi.org/10.1007/s1045

Somarriba, E.; Cerda, R.; Orozco, L.; Cifuentes, M.; Dávila, H.; Espin, T.; Mavisoy, H.; Ávila, G.; Alvarado, E.; Poveda, V.; Astorga, C.; Say, E.; Deheuvels, O. Carbon stocks and cocoa yields in agroforestry systems of Central America. Agriculture Ecosystems Environment, v.173, p.46-57, 2013. https://doi.org/10.1016/j. agee.2013.04.013

Tiepolo, G.; Calmon, M.; Feretti, A. R. Measuring and monitoring carbon stocks at the Guaraqueçaba climate action project, Paraná, Brazil. In: International Symposium on Forest Carbon Sequestration and Monitoring. Extension Serie Taiwan Forestry Research Institute, v.153, p.98-115, 2002.

Torres, C. M. M. E.; Jacovine, L. A. G.; Oliveira Neto, S. N. D.; Brianezi, D.; Alves, E. B. B. M. Sistemas agroflorestais no Brasil: Uma abordagem sobre a estocagem de carbono. Pesquisa Florestal Brasileira, v.34, p.235-244, 2014. https://doi.org/10.4336/2014. pfb.34.79.633

Tsuchiya, A.; Hiraoka, M. Forest biomass and wood consumption in the lower course of the Amazon: A case study of the Urubuera Island. Acta Amazonica, v.29, p.79-95, 1999.

Vaast, P.; Somarriba, E. Trade-offs between crop intensification and ecosystem services: The role of agroforestry in cocoa cultivation. Agroforestry Systems, v.88, p.947-956, 2014. https:// doi.org/10.1007/s10457-014-9762-x 